\title{
Assessing the Application of International Accounting Standards (IAS) in Jordan: Factors Explaining Non-compliance
}

\author{
Husni K. Al-Shattarat \\ Zarqa University, Zarqa, Jordan
}

\begin{abstract}
The main objective of this study is to assess the application of International Accounting Standards (IAS) in Jordan. The main purposes of this study are to: (1) present an analyzed study of the general concepts of IAS; (2) clarify the suitability of the IAS in Jordan and the possibility of using them as guidelines in adapting local standards; and (3) state the deficiency aspects and difficulties facing Jordanian firms in applying these standards in local businesses. A questionnaire is designed for these purposes. The sample is restricted to accountants, financial executives, and professional members of the Jordan Association of Accountants and Auditors. We used the Statistical Package for Social Sciences (SPSS) to analyze the data and answer the research questions. Descriptive statistics are the main tests used in this study. The results indicate that IASs are necessary to be applied by Jordanian companies, since the advantages of applying IAS in Jordan are seen to be more than its disadvantages, mainly in the scene of improving the information content of financial statements. The results also indicate that the compliance with IAS will be of great benefits to shareholders and the stock market comparing to its benefits to top management and board members. Auditors, accountants, and financial executives argue that government agencies in Jordan should enforce and supervise the implementation of IAS in Jordan.
\end{abstract}

Keywords: International Accounting Standards (IAS), questionnaire, standards’ compliance, Jordan

\section{Introduction}

Proper and trustful information is one of the essential beams needed by investors, creditors, and other users of financial information to make their decisions. International economic development, increasing interest towards globalization of economic activities, and the resulting necessity to ease the process of transferring capitals among international markets lead to realizing the importance of having a degree of compatibility between accounting information prepared and disclosed by companies in different countries.

The efficiency of the accounting information depends mainly on the level of perfection and quality of the accounting standards used in preparing these data. Accounting standards present rules and guidelines that should help in preparing financial reports containing proper, reliable, and internationally consistent and comparable information. The mission of the International Accounting Standards Board (IASB), which replaced the International Accounting Standards Committee (IASC), is to develop a single set of high-quality, understandable, and enforceable global accounting standards and work with national standard setters, such as the Financial Accounting Standards Board (FASB), to achieve worldwide convergence or harmony.

Husni K. Al-Shattarat, assistant professor, College of Business Administration, Zarqa University. Email: shattarat.hu@gmail.com. 
Harmony helps ensure the consistency of accounting and reporting among all countries, which results in better and more efficient financial analyses of companies. This will result in more efficient flows of capital, because investors will not have to assign risk premiums to companies operating in countries with inconsistent or low-quality accounting standards. Finally, harmony will reduce costs, because accountants, auditors, financial analysts, investors, and regulators will no longer be converting or reconciling financial statements from one set of the Generally Accepted Accounting Principles (GAAP) to another.

IASC responded to the foresaid by issuing a complete set of accounting standards that were adopted by many countries. Convergence of international accounting standards is not a new initiative at the FASB; in fact, the FASB has pursued international "convergence" for almost half of its more than 30 years existence. The FASB's international activities initially fell under the heading of harmonization or internationalization of accounting standards. Today, those activities are referred to as convergence. Whatever the term, the board has long held the view that a single set of high-quality international accounting standards are desirable, because its use will improve the international comparability of financial information. Over time, the FASB's role in the international accounting arena has evolved from that of a participating observer involved with a few collaborative efforts to an active participant with the convergence goal integrated into all aspects of its processes and activities. It is required that all Jordanian companies commit in applying international accounting standards when preparing and presenting financial data in order to achieve the aimed compatibility between Jordanian companies and its equals in the world.

\section{Literature Review}

While the IASC, now recently renamed as the IASB, has emerged in 2001 as a restructured and viable accounting standard setter that has achieved much since its formation in 1973, there are concerns that a comprehensive infrastructure must be in place so that high-quality international accounting and financial reporting standards can be used, interpreted, and enforced consistently throughout the world. The focus of attention is thus switching from accounting standard setting to enforcement. The International Federation of Accountants (IFAC) has stated that although auditors are asserting that financial statements comply with International Accounting Standards (IAS), the accounting policies and notes sometimes indicate otherwise. Prior research supports IFAC's view that non-compliance with IAS is problematic.

The idea of harmonizing accounting practices on a worldwide basis has a long history. However, it was only after World War II that the essential preconditions for this emerged: active business expansion by transnational enterprises, growth in international commerce, and development of financial markets. Indeed, it was the internationalization of financial markets in the late 1980s that became the main impetus for developing and implementing IAS. Even in China, it has been suggested that reconciling the differences between accounting standards adopted in the People's Republic of China (PRC) and Western countries will help to pave the way for the harmonization of the PRC's accounting standards with international accounting practices (Ng, 1999).

In 1973, public accounting (audit) firms from several countries (including Australia, the Great Britain, Germany, Canada, the US, and France) established an international non-governmental organization, the IASC, to act as an independent accounting standard setter. In the early 1990s, IAS gradually began to earn acceptance within leading world markets. This process received considerable support from both the International Organization of Securities Commissions (IOSCO), which recommended that all companies seeking international listings implement IAS, and the Basle Committee on Banking Supervision. 
According to Samuels and Piper (1985), accounting harmonization attempts to bring together different systems leading to the process of blending and combining various practices into an orderly structure, which produces synergistic results. While some see harmonization more as a process of moving to a system of uniformity or standardization, most view harmonization as a process whereby the number of allowed accounting alternatives is reduced as a means of promoting greater comparability (Larson \& Kenny, 1999).

These changes marked the beginning of a global trend towards the adoption of IAS. Indeed, over 50 countries throughout the world have adopted special programs for transitioning to or converging their national standards with IAS. The European Union (EU) has issued a directive making the use of IAS mandatory starting from 2005 for all companies listed in European securities markets when preparing their consolidated financial statements. Australia has announced that it will make a full transition to IAS starting from 2005. And, the US FASB has signed an agreement with the IASB, aiming at eliminating differences between US GAAP and IAS and bringing the two reporting systems closer together.

\section{IASB}

IAS was issued by the antecedent International Accounting Standards Council and was endorsed and amended by the IASB. ${ }^{1}$

The IASB is an independent organization based in London, UK, which issues accounting rules known as International Financial Reporting Standards (IFRS) previously known as IAS. The IAS was renamed as IFRS. In 2002, US FASB and IASB held a joint meeting and issued a memorandum of understanding pledging convergence of their accounting standards and coordination of their work programmes. In 2004, the European Commission endorses all IASs and IFRSs for use in Europe. These countries include Austria, Belgium, Cyprus, the Czech Republic, Denmark, Germany, Estonia, Greece, Spain, France, Ireland, Italy, Latvia, Lithuania, Luxembourg, Hungary, Malta, the Netherlands, Poland, Portugal, Slovenia, Slovakia, Finland, Sweden, and UK. During the same period, Australia, Hong Kong, New Zealand, and the Philippines adopt the improved IASs and IFRSs.

Several countries that had not adopted IFRS had established machinery for convergence. Convergence is a modified version of adoption. Ball (2006) narrated that convergence de facto is less certain than convergence de jure. The latter relates to accounting regulation, while the former relates to company practices. That is to say that harmony in actual financial reporting practices is different from harmony in financial reporting standards (Taplin, Tower, \& Hancock, 2002). The IFRS offers advantages such as accurate, timely, and comprehensive financial statement information, reduces cost of information processing, enhances international comparison of financial statements, and removes barriers to cross-border acquisitions and divestitures (Ball, 2006).

\section{The Need for IAS}

As we start the new millennium, international economic activity along with other international activities has been increasing at a very rapid rate. International trade, capital movements among countries, international investment, number of multinational firms, and international bond and equity offerings exhibited a huge growth over the last decade. Dealing with accounting diversity and the requirements of different national accounting

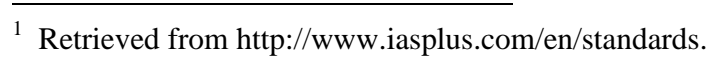


standards was a major and costly problem for these companies. If all countries of the world employ the same accounting standards, such as international accounting standards, multinational companies stand to gain tremendously.

Another interest group, who could benefit from the global harmonization of accounting principles, is the international investor. With the arrival of high-tech computers and information age, massive amounts of international financial information are available on the internet. More and more institutional and individual investors are interested in making international investments.

Other groups, which may be interested in universal harmonization of accounting principles, include international filer companies, international accounting firms, international intergovernmental organizations, governments and regulating bodies, and financial markets. A short discussion of these groups is as follows:

(1) Some companies listed in large stock exchanges are not multinationals, but they are interested in raising additional funds and trading securities with favorable terms. However, the regulating bodies of stock exchanges, such as the Securities and Exchange Commission (SEC) in USA, place restrictive filing requirements. Usually, they require financial statements to be prepared according to the domestic financial reporting standards. Adoption of the IASs would remove such restrictions;

(2) International accounting firms constitute another group. They provide auditing and consulting services in many countries. In order to perform these services, they must possess expertise in the area of domestic financial accounting principles and the related laws. Development of this expertise is very costly to these firms and global harmonization of accounting principles would be likely to reduce these costs substantially;

(3) International intergovernmental organizations, such as the United Nations (UN), the EU, and the Organization for Economic Cooperation and Development (OECD), are also interested in obtaining comparable financial information. These organizations need to evaluate projects, extend credits, and make other decisions about the different nations of the world. Worldwide accounting principles would produce comparable financial information needed by these organizations;

(4) Many developing countries as well as the Eastern European countries did not experience the problems of developed countries and their domestic accounting standards are not very comprehensive. If the governments and/or accounting regulating bodies of these countries adopt international accounting standards as their national standards, they can not only have a comprehensive set of standards but also may have easier access to international financing sources;

(5) International accounting standards can be very important for the development of global financial markets, especially for stock exchanges. This will be discussed in more detail in the next section.

According to the advocates of accounting harmonization, whether on a regional or global basis, there are four primary benefits. These are cost savings accruing to multinational companies, enhanced comprehensiveness and comparability of cross-national financial reports, widespread dissemination of high-quality accounting standards and practices, and provision of low-cost financial accounting standards to countries with limited resources (Aitken \& Islam, 1984).

In 2001, the Australian Accounting Standards Board (AASB) issued an exposure draft concerning International Convergence and Harmonization Policy for comment. The main benefits of convergence and harmonization, according to this exposure draft, are: 
(1) Increasing the comparability of financial reports prepared in different countries and providing participants in international capital markets with better quality information on which to base investment and credit decisions;

(2) Removing barriers to international capital flows by reducing differences in financial reporting requirements for participants in international capital markets;

(3) Reducing financial reporting costs for Australian multinational companies and foreign companies;

(4) Facilitating more meaningful comparisons of the financial performance and financial position and improving the quality of financial reporting. ${ }^{2}$

\section{Factors Impacting the Level of Disclosure and Compliance With IAS}

Accounting standards, such as IAS, set out minimum disclosure guidelines that companies are obliged to follow. However, the IASC and IFAC are concerned that some companies claiming to comply with IAS may not in fact be complying with all the requirements of IAS. In this regard, the President of the IFAC has criticized auditors for asserting that financial statements comply with IAS, when the accounting policies and other notes show otherwise. Street and Bryant (2000) supported the assertions of the IASC and IFAC by providing evidence that the degree of compliance by companies claiming to comply with IAS is very mixed and somewhat selective. The findings of this study reinforce the significance of the acceptance and observance issue for the IASC.

Several studies have addressed the impact of various corporate characteristics on annual report disclosures and compliance with IAS. These characteristics include size, listing status, leverage, profitability, industry, type of auditor, size of the equity market, degree of economic development, type of economy, activity on the equity market, dispersion of stock ownership, and culture. Studies based on capital markets in developed countries include Wallace and Naser (1995), Inchausti (1997), and Dumontier and Raffournier (1998). Overall, these studies indicate that size and listing status are significantly associated with the level of disclosure.

Findings regarding the relationship between level of disclosure and other corporate variables have been mixed. Wallace and Naser (1995) provided evidence of an association between profitability (rate of return) and level of disclosure.

On the local side of Jordan, Juhmani and Ayling (1996) investigated the effect of introducing IAS on Amman Financial Market. He compared the stock returns of both sample and control groups around the earnings announcement over a short window in the year of adoption and the preceding year. He reported that the stock returns in the adoption year were different from the preceding year and concluded that the adoption of IAS resulted in new relevant information being revealed. This paper controls for these variables and extends the window to cover the whole year of adoption to capture any announcement or leakage of such news during the year. This research is of great importance for both the IASC and the policy makers of developing countries. IASC promotes the adoption of IASs on the grounds that they facilitate the development of equity markets and economic growth. Policy makers of other developing countries can use the findings of this research to decide on whether their countries should adopt IASs. The findings reveal a significant impact on stock prices of adopting firms compared to non-adopting firms. The results were more significant for the smaller firms. The results give evidence of the value of IAS for investors and give further impetus towards international accounting harmonization.

\footnotetext{
${ }^{2}$ Retrieved from http://www.aasb.com.au/workprog/docs/102_7-01.pdf.
} 


\section{Obstacles to Convergence With IAS}

The obstacles against accounting harmonization give an insight into what a complex issue this is and an appreciation of the problems facing the development of international accounting. Therefore, it is very important to understand the obstacles when studying international accounting harmonization (Lawrence, 1996).

A recent survey, GAAP Convergence 2002 (conducted by PricewaterhouseCoopers jointly with five other leading international audit firms), demonstrates that the complexity of some IASs is one of the most serious obstacles to converging national accounting rules or GAAPs, in different countries around the world, with IAS. The most exacting aspect of IAS involves the recognition of financial instruments, in particular investments in securities, derivatives, accounts receivable, and accounts payable. Such assets and liabilities must be fair valued, which can often be a complicated task for some accounting specialists. In addition, there are a number of other obstacles to convergence, such as:

(1) Complexity of individual standards;

(2) National accounting rules focused primarily on tax reporting;

(3) Divergence with certain key IAS;

(4) Lack of detailed instructions for the first-time application of IAS;

(5) Capital market restrictions;

(6) Acceptability of national accounting standards for investors/users;

(7) Translation difficulties.

The tax-driven nature of the national accounting regime was identified as an obstacle to convergence in almost half of the countries surveyed. In countries where one of the primary objectives of the accounting standards traditionally has been to determine taxable income, the existing link between accounting and tax is seen as a potential barrier to convergence. Financial statements prepared in accordance with IFRS are intended primarily to serve the needs of the capital markets, which may differ significantly from the needs of the tax authorities.

Respondents in over one third of the countries surveyed indicated that difficulties in achieving convergence have been experienced or are expected to be experienced as a result of disagreements with the approach taken in certain IFRS. Again, the most frequently cited points of contention are financial instruments and other standards incorporating fair value accounting.

The findings in respect of IFRS training reveal that IFRS is part of the university curriculum in $80 \%$ of the countries covered. However, over one third of the respondents who indicated that IFRS is included in the curriculum qualified their responses by stating that the coverage is limited or offered by only a few universities within the country. In nearly $30 \%$ of the countries, IFRS training in the national language is not provided by professional organizations, and therefore, is not readily available to either preparers or auditors of financial statements.

The development of accounting must be considered, since the historical development of accounting in each country is different. Therefore, the starting point to get into the harmonization process is also different. For countries which have a history of using accounting standards produced by independent private-sector bodies, it may be easier to use international accounting standards rather than countries that use governmental guidelines (Lawrence, 1996). The development of a professional accounting body plays an important role in the process of accounting harmonization in a country. It is difficult, therefore, for countries that lack such a body to pursue the harmonization process. 
Organizations, both public- and private-sector, influence the process of accounting harmonization even though they have different goals and ambitions (Lawrence, 1996). Each of them has different expectations as to suitable accounting practices and necessary financial disclosure. For example, the UN requires that disclosure of multinational enterprises (MNEs) in the developing countries in which MNEs operate be extended. The OECD focuses on the extent of the disclosure from the point of view of the developed country where the MNE is based.

The process of accounting harmonization is very time-consuming. To accomplish an international standard, at least months or years are needed, and it will also take time for a standard to be applied. As globalization is speeding up, it will clearly be difficult as well as costly to keep the standards and the due process up to date. The competition among countries, in order to attract investors, can lead to quick movements, where changes can happen many times in a short term. The business environments have a short time focus, and in short time, the costs of harmonization may seem to be high. Governments often have a shorter time focus, since they rely on voters for a limited period of time. The benefits of harmonization might not be visible during their reign. Should the political environment in the country not accept the international rules, for accounting or others, the "punishment”, such as trade wars, may be costly, not only in monetary terms but also in human suffering.

Harmonization tends to assume that all countries are at the same level in terms of economic development. In fact, there are great differences among countries. The world has globally accepted that countries vary very much in many aspects. Harmonization assumes the idea that all can apply one set of rules. Within the industrialized world, the benefits may exceed the cost of harmonization. They already have professional bodies, strong economies, and good education. But in the underdeveloped world, adoption of the standards may not be possible. The cost to hire professional accountants can instead be invested in lower-level education that will give the country a better starting point. The investments in harmonization will only be costly.

\section{Data and Methodology}

\section{Research Importance and Objectives}

The importance of this study arises from the fact that actual application of these standards in local companies in Jordan showed some difficulties and obstacles that should be studied and analyzed. The main objectives of this study are to:

(1) Present an analyzed study of general concepts of international accounting standards and most important topics that are not considered when applying these standards in Jordan;

(2) Clarify the suitability of the international accounting standards for application at the local level of Jordan and the possibility of using them as guidelines in adapting local standards;

(3) State the deficiency aspects and difficulties facing Jordanian firms in applying some of these standards in local businesses;

(4) Suggest proposed solutions to facilitate the use of IAS in Jordanian enterprises.

\section{Research Questions}

This study tries to answer the following questions:

(1) What are the main advantages of applying IAS in Jordan?

(2) What are the main obstacles for applying IAS in Jordan?

(3) Which topics of IAS are not considered in Jordan? 
(4) To what extent is IAS suitable to be applied in Jordan?

(5) Do companies provide accountants with sufficient guidelines, support, and authorities to apply IAS?

(6) Do auditing firms play a role in encouraging their clients to apply IAS?

(7) What is the role played by governmental agencies and stock market authorities to encourage companies to apply IAS in Jordan?

(8) Is there any relationship between the use of technology and information systems and the application of IAS in Jordan?

\section{Sample and Data}

The data for this study are collected from different sources. A questionnaire is designed for this purpose. The sample is restricted to accountants, financial executives, and professional members of the Jordan Association of Accountants and Auditors. Two sets of questionnaires are distributed. The first set includes accountants and financial executives working at Jordanian listed companies. The second set is distributed among auditors. The samples were randomly selected and questionnaires were distributed among 72 listed companies and 45 auditing firms. Response rates were $75 \%$ and $80 \%$ respectively (54 and 36 completed questionnaires were collected from listed companies and auditors, respectively).

In order to achieve the goal of this study, a questionnaire is prepared containing a number of questions divided into three groups:

(1) First group: general information about the accounting and auditing in Jordan;

(2) Second group: related to the difficulties and obstacles that prevent Jordanian firms from applying international accounting standards;

(3) Third group: The effect of those difficulties and challenges on the accuracy and safety of financial data on the users (decision makers-investors).

Vital information is provided by both: (1) accountants and financial executives in firms listed in the security exchange; and (2) professionals (auditors) in the Jordan Association of Accountants and Auditors.

Each of the research questions is measured by a set of statements covering all dimensions of a variable (question). These statements are demonstrated in a form of a questionnaire that is spread among accountants, financial executives, and professionals in the Jordan Association of Accountants and Auditors. The statements are weighted individually, depending on the importance of each based on a 5-point scale ranging from 1 (does not agree at all) to 5 (strongly agrees).

The questionnaire also includes some open questions mainly requiring listing the main difficulties and obstacles facing the application of IAS in Jordan and suggesting solutions to improve its use by listed Jordanian companies.

\section{Statistical Tests Employed}

We used the Statistical Package for Social Sciences (SPSS) to analyze the data and answer the research questions. Descriptive statistics are the main tests used in this study.

\section{The Empirical Results}

The results indicate that IAS is necessary to be applied by Jordanian companies, since the advantages of applying IAS in Jordan are seen to be more than its disadvantages, mainly in the scene of improving the information content of financial statements and information. 
The results also indicate that the compliance with IAS will be of great benefits to shareholders and the stock market comparing to its benefits to top management and board members. Applying IAS will also help Jordanian companies to join the World Trade Organization (WTO).

Auditors, accountants, and financial executives argue that government agencies in Jordan should enforce and supervise the implementation of IAS by the companies. They did not agree with the idea that it is impossible to apply IAS by Jordanian companies.

The results point out that from accountants and financial executives' point of view, applying IAS will increase the work load of accountants, consume more time to prepare financial statements, and will make accountants' jobs more complicated. However, from auditors' point of view, this is not the case.

Table 1 below indicates the mean responses of auditors and accountants and financial executives on the dimensions covering the importance, necessity, and relevance of applying IAS in Jordan.

Table 1

The Importance, Necessity, and Relevance of Applying IAS in Jordan

\begin{tabular}{|c|c|c|}
\hline Dimension & Mean (Auditors) & $\begin{array}{l}\text { Mean (Accountants and } \\
\text { financial executives) }\end{array}$ \\
\hline It is necessary to apply IAS by Jordanian companies. & 4.18 & 3.95 \\
\hline All Jordanian companies must comply with IAS. & 3.98 & 4.02 \\
\hline Applying IAS will help Jordan to join the WTO. & 3.68 & 3.96 \\
\hline $\begin{array}{l}\text { Government agencies should enforce and supervise the implementation of IAS } \\
\text { by the companies. }\end{array}$ & 3.75 & 3.62 \\
\hline Applying IAS will increase the work load of accountants. & 3.01 & 3.53 \\
\hline Applying IAS will consume less time to prepare financial statements. & 3.26 & 3.45 \\
\hline Applying IAS will make accountants' jobs more complicated. & 3.08 & 3.85 \\
\hline \multicolumn{3}{|l|}{ Applying IAS will be beneficiary for: } \\
\hline Board members & 3.15 & 3.49 \\
\hline Top management & 3.11 & 3.47 \\
\hline Shareholders & 3.28 & 3.61 \\
\hline Stock markets & 3.98 & 4.17 \\
\hline The advantages of applying IAS in Jordan are more than its disadvantages. & 4.22 & 3.88 \\
\hline $\begin{array}{l}\text { Applying IAS shall improve the information content of financial statements } \\
\text { and information. }\end{array}$ & 4.15 & 4.06 \\
\hline It is not possible to apply IAS in companies in Jordan. & 3.01 & 3.33 \\
\hline There is a possibility to apply some (but not all) IAS in Jordan. & 4.26 & 4.27 \\
\hline Financial statements are losing its information relevance. & 4.27 & 4.05 \\
\hline There is a high level of trust in IAS to be applied in Jordan. & 3.99 & 4.03 \\
\hline IAS is suitable for application at the local level of Jordan. & 3.97 & 4.01 \\
\hline $\begin{array}{l}\text { There is a possibility of using IAS as guidelines in adapting local Jordanian } \\
\text { standards. }\end{array}$ & 3.78 & 4.03 \\
\hline IAS is relevant to Jordanian companies. & 3.65 & 3.81 \\
\hline IAS is easy to present and apply. & 3.42 & 3.67 \\
\hline IAS is efficiently applied by your company. & 3.82 & 3.97 \\
\hline ISA is efficiently applied in Jordan. & 3.90 & 3.81 \\
\hline
\end{tabular}

The results also indicate that both auditors and government agencies, mainly the Jordan Stock Market, play an essential role in encouraging companies to apply IAS in Jordan. The respondents of auditors and accountants and financial executives confirm this (see Table 2 below). 
Table 2

The Role of Auditors and Government Agencies in Encouraging Companies to Apply IAS in Jordan

\begin{tabular}{lll}
\hline Dimension & Mean (Auditors) & $\begin{array}{l}\text { Mean (Accountants and } \\
\text { financial executives) }\end{array}$ \\
\hline $\begin{array}{l}\text { Auditing firms are strictly requiring companies to apply IFRS in Jordan. } \\
\text { Stock market authorities are requiring Jordanian listed firms to prepare }\end{array}$ & 4.12 & 4.02 \\
their financial information in compliance with IFRS. & 4.11 \\
Jordanian law enforces companies to apply IAS. & 4.29 & 4.22 \\
The law requests all accountants to be trained on how to apply IAS. & 4.01 & 3.98 \\
We are committed by law to ensure that our clients are applying IAS. & 4.11 & 3.99 \\
Auditing firms are strictly requiring companies to apply IFRS in Jordan. & 4.01 & 3.92 \\
\hline
\end{tabular}

Both groups agree that:

(1) Auditors and accountants in Jordan are well trained and always follow new IAS, and staff is getting continuous training on IAS;

(2) Auditing firms in Jordan are well qualified to guarantee relevant applications of IAS by their clients.

Not surprisingly, accountants and financial executives argue that external auditors sometimes prefer not to apply IAS. On the other hand, auditors strongly indicate that some of their clients resist applying IAS.

The results indicate that the main advantages of applying AIS in Jordan include:

(1) Increasing comparability of financial reports prepared and providing participants from international capital markets with better quality information on which to base investment and credit decisions;

(2) Removing barriers to international capital flows by reducing differences in financial reporting requirements;

(3) Reducing financial reporting costs for Jordanian companies and foreign companies;

(4) Facilitating more meaningful comparisons of the financial performance and financial position;

(5) Comprehensiveness and comparability of cross-country financial reports and international financial information.

\section{Recommendations}

The following recommendations are outlined, which will be useful to stakeholders such as accountants, auditors, company managers, investors, financial analysts, stock brokers, and the regulatory bodies responsible for accounting standard setting and stock market regulations:

(1) Applying IAS will provide investors with comparable information about companies' financial position and performance, which can be used as a basis for their investment decisions;

(2) Applying IAS will provide bankers with all relevant and comparable information they need to be used as a basis for making lending and credit decisions and to satisfy accountability objectives. They evaluate and predict the risk of default on obligations to pay loan interest and refund the loans when due;

(3) Applying IAS will increase the work load of accountants in a subsidiary company, and it will be easier to prepare financial reporting to a parent company if they share similarities in accounting standards. Conversely, for accountants in a parent company, it will be easier to make consolidated financial statements if there are similarities in the accounting standards.

\section{References}

Aitken, M. J., \& Islam, M. A. (1984). Dispelling arguments against International Accounting Standards. International Journal of Accounting Education and Research, 19(2), 35-46. 
Ball, R. (2006). International Financial Reporting Standards (IFRS): Pros and cons for investors. Accounting and Business Research, International Accounting Policy Forum, 5-27.

Dumontier, P., \& Raffournier, B. (1998). Why firms comply voluntarily with IAS: An empirical analysis with Swiss data. Journal of International Financial Management and Accounting, 9(3), 216-245.

Inchausti, B. G. (1997). The influence of company characteristics and accounting regulation on information disclosed by Spanish firms. European Accounting Review, 6(1), 45-68.

Juhmani, O., \& Ayling, D. (1996). The stock market response to the introduction of international accounting standards in Jordan. Research Paper in Banking and Finance, University of Wales Bangor, Vol. 29.

Larson, R. K., \& Kenny, S. Y. (1999). The harmonization of International Accounting Standards: Progress in the 1990s? Multinational Business Review, 7(1), 1-12.

Lawrence, S. (1996). International accounting. London: International Thomson Business.

Ng, A. (1999). Harmonisation and China: Problems aplenty. Australian CPA, 69(5), 32-33.

Samuels, J. M., \& Piper, A. G. (1985). International accounting: A survey. New York, NY: St. Martin’s Press.

Street, D. L., \& Bryant, S. M. (2000). Disclosure level and compliance with IASs: A comparison of companies with and without U.S. listings and filings. The International Journal of Accounting, 35(3), 305-329.

Taplin, R., Tower, G., \& Hancock, P. (2002). Disclosure (discernibility) and compliance of accounting policies: Asia-Pacific evidence. Accounting Forum, 26(2), 172-190.

Wallace, R. S. O., \& Naser, K. (1995). Firm-specific determinants of the comprehensiveness of mandatory disclosure in the corporate annual reports of firms listed on the stock exchange of Hong Kong. Journal of Accounting and Public Policy, 14(4), 311-368. 